\title{
Behaviour of Strength Properties of Fast-Growing Endospermum diadenum Species at Different Distance from the Vortex
}

\section{Gaddafi ISMAILI ${ }^{1}$ *, Rosmiani ROSLANI ${ }^{1}$, Khairul Khuzaimah ABDUL RAHIM ${ }^{2}$, Alik DUJU ${ }^{2}$, Zurina ISMAILI ${ }^{3}$, Iskanda OPENG ${ }^{4}$, Mohammad Nazriq ILIAS ${ }^{5}$}

\author{
${ }^{1}$ Universiti Malaysia Sarawak, Faculty of Engineering, Civil Engineering Department, 94300 Kota Samarahan, Sarawak \\ ${ }^{2}$ Sarawak Forestry Corporation, 93250 Kuching, Sarawak, Malaysia \\ ${ }^{3}$ School Engineering and Technology,University College of Technology Sarawak, 96000 Sibu, Sarawak \\ ${ }^{4}$ Faculty of Civil Engineering, Universiti Teknologi MARA, 94300 Kota Samarahan, Sarawak, Malaysia \\ ${ }^{5}$ Faculty of Manufacturing Engineering, Universiti Teknikal Malaysia Melaka, 76100 Durian Tunggal, Melaka, Malaysia
}

crossref http://dx.doi.org/10.5755/j01.ms.23.3.16642

\section{Received 31 October 2016; accepted 30 January 2017}

\begin{abstract}
The data performance for structural usage of highly engineered wood is very useful, however, the lacking of the data is very much concern for fast-growing indigenous timber species in timber engineering field. In correlation with that, the strength properties behaviour of Endospermum diadenum has to be studied to analyse the distribution pattern of strength properties at a different distance from the vortex also known as pith. The species have been obtained from the East Campus of Universiti Malaysia Sarawak's forest reserve. Strength properties test were carried out namely, static bending (modulus of rupture - MOR and modulus of elasticity - MOE), and the compressive strength (compression stress parallel to grain). Meanwhile, physical properties test was carried out namely, moisture content (MC) and density. Small specimens measuring 20 × $20 \mathrm{~mm}$ were tested in green and dry conditions in accordance with British Standard, BS 373:1957 (British Standards Institution, 1957). The green condition refers to moisture content greater than 19 percent and dry condition with moisture content less than or equal 19 percent. All the results that had been tested were analyzed using statistical analysis as mean results. The strength properties of specimen increased from the pith towards the sapwood in which the strength is the lowest at $25 \mathrm{~mm}$ from pith followed by $50 \mathrm{~mm}$, and the highest is at $75 \mathrm{~mm}$ from the pith. Distribution of the basic density also increases slightly from the pith towards the sapwood with a significant increment in average mean value at $25 \mathrm{~mm}$ from vortex with $0.54 \mathrm{~g} / \mathrm{cm}^{3}, 0.62 \mathrm{~g} / \mathrm{cm}^{3}$ at $50 \mathrm{~mm}$ and $0.66 \mathrm{~g} / \mathrm{cm}^{3}$ at $75 \mathrm{~mm}$ from the vortex. Meanwhile, for dry condition, the increases in average mean value with $0.425 \mathrm{~g} / \mathrm{cm}^{3}$ at $25 \mathrm{~mm}, 0.427 \mathrm{~g} / \mathrm{cm}^{3}$ at $50 \mathrm{~mm}$ and $0.47 \mathrm{~g} / \mathrm{cm}^{3}$ at $75 \mathrm{~mm}$ from the vortex. It can be concluded that the physical properties of the wood have a direct impact on the wood stiffness and strength.

Keywords: vortex, pith, sapwood, strength properties, physical properties.
\end{abstract}

\section{INTRODUCTION}

Timber is one of the primary construction materials since the earliest centuries. It is a natural resource that is widely available in the world. Timber is used as a major structural material in a great variety of building and civil engineering application such as bridges and roof trusses. It is also widely used in manufacturing product such as furniture and flooring.

Timber has the advantages over most other structural materials of being renewable and also a relatively good thermal insulation material [1]. The energy consumption during production is very small compared to other building material like concrete and steel. Due to the low energy required and low pollution during manufacture, timber has a far less detrimental impact on the environment compared to other building material. Timber has a high strength to weight ratio, which makes it easily shape and benefit from the construction and production of timber product. Furthermore, timber has a very aesthetic value that offers a great impression in architectural design.

\footnotetext{
* Corresponding author. Tel.: +6082-58-3343; fax: +6082-58-3410.

E-mail address: igaddafi@unimas.my (G. Ismaili)
}

In Malaysia, the timber industry has become one among the long-standing prominence that contributes to the growth of the economy. As the country is rich with rainforest and tropical land, the availability of timber is unconstrained hence resulting Malaysia become one among the sustainable timber exporter around the world. As a result, Malaysia aggressively promoted activities and research to supply higher quality and value-added commercial timber product. Sarawak is known as the richest region with flora and fauna consisting of numerous indigenous species of fast-growing timber [2]. The effort has been taken by introducing fast growth indigenous timber species for plantation and research had been conducted to perceive suitable and potential indigenous timber species for light hardwood industries utilisation and for engineering structural design purposes [3, 4].

The strength properties of wood are classified according to its density, durability, moisture content, and direction of grain [5]. The density of timber is understood to be relatively reflected the strength of timber, but it should not be the definite measurement of its strength [6]. Moreover, timber is homogenous material therefore, some physical 
testing had to be conducted to reveal and confirmed the timber strength group as identified from its density [7]. In the usage of timber for structural purposes, the strength properties of timber are of prime importance. The strength required for a timber varies, depending on the load that the structure is expected to carry. Obviously, the heavier the loading, the stronger the timber necessary to support it [8]. A detailed knowledge how the tree growth and structure of wood are essential to the design of efficient timber structures [9].

The species of timber used for this study is Endospermum diadenum. Endospermum diadenum can be classified as light hardwood timber, and its natural habitat was in a primary forest on low, undulating country or along streams and occasionally on permanently inundated sites such as Malaysia, Thailand, Sumatera and Borneo. Although it is often found in association with other typical swamp forest species, it is also known as opportunist species characteristic through gaps in the forest and, therefore, is commonly found in areas with shifting cultivation. It is also being planted after the site clearing for land appeal due to its fast growth [10].

The aim of this study is to determine the influence on the strength properties of Endospermum diadenum at difference distance from the vortex. To achieve this, there are several objectives should be taken consideration. Firstly is to determine the physical and mechanical properties of Endospermum diadenum related to the strength of material. Secondly is to evaluate on how Endospermum diadenum will react when applied with a load in both flexural and compressive strength at a different distance from the vortex.

\section{METHODOLOGY}

\subsection{Preparation of material}

The sample for the experiment used was Endospermum diadenum, and it was taken from the forest that is located at East Campus of Universiti Malaysia Sarawak. There are three trees same species age five years old were collected which identified as TR008, TR010, and TR013. The trees were cut approximately 30 centimeters above the ground with the diameter at breast height over the bark of trees is approximately $20 \mathrm{~cm}$ at the height of $1.3 \mathrm{~m}$ from the root collar. Timbers were cut to obtain different tree section namely at the bottom, middle and top. Each section was cut into 1.5 meters. After the sample had been collected, the sample was then transported to Sarawak Forestry Corporation (SFC) for the preparation of materials and laboratory testing. In this study, Endospermum diadenum is used as the sample for the laboratory test. Due to the inhomogeneous features of timber, a large number of specimens are required for the testing. There were 120 specimens used for every testing. Therefore, a total number of 1440 specimens were used in this study. The log was ripped through the pith to obtain the flitches. The specimen for the test is a small clear specimen, therefore, accordance with British Standard 373:1957, the small clear specimen dimension of $20 \mathrm{~mm} \times 20 \mathrm{~mm}$ is used [11]. All specimens are taken out from a single tree at a different distance from its pith to compare the strength properties and to verify certainly the inhomogeneity of the timber itself. For this study, as shown in the Fig. 1 the distance from pith or vortex had been segmented into three section at $25 \mathrm{~mm}, 50 \mathrm{~mm}$ and $75 \mathrm{~mm}$ centre to centre after considering the cutting sawn allowable, tree diameter, and specimen dimension.

\subsection{Laboratory work}

The prepared sample is taken to the laboratory for further testing. All the sample tested is according to the small clear test specimen adopted from British Standard 373:1957, Method of Testing Small Clear Specimens of Timber. To achieve an accurate result, the physical properties of the sample are tested before any strength test is being conducted. Two types of physical properties were taken into consideration, which are the moisture content and basic density. For moisture content test, the samples obtained shall be weighed immediately after cutting to obtained green condition with MC > $19 \%$. If the test pieces cannot be weighed immediately, placed them inside a plastic bag to protect them from moisture changes. All samples were dried in an oven with the temperature of $103 \pm 3{ }^{\circ} \mathrm{C}$ for 24 hours or until constant weight is obtained. In order to achieve accurate results, the sample should be kept in a desiccator before re-weighing. The samples are weighed again in order to obtain the oven-dry weight with MC $\leq 19 \%$. The moisture content is calculated using the formula given:

$$
M C \%=\frac{\text { initial weight }- \text { oven weight }}{\text { oven dried weight }} \times 100 \text {. }
$$

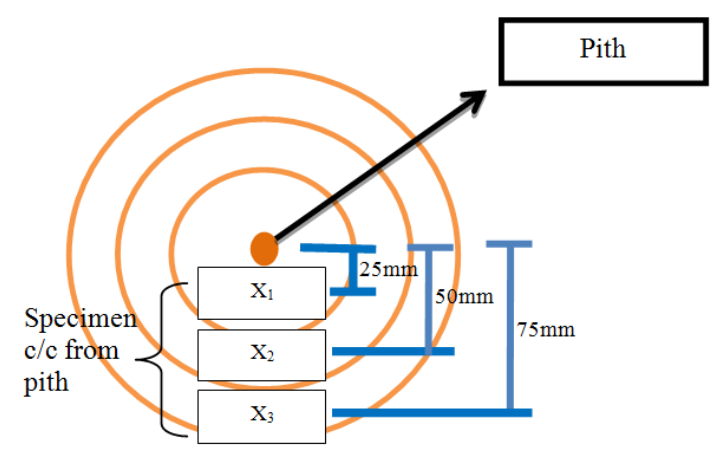

Fig. 1. The position of specimen taken at different distance from the pith

In the procedures outlined, the initial weighing gives the total weight of wood substances, and moisture in the section and the final oven-dry weight is that of wood substances alone. By subtracting the oven-dry weight from the initial weight, the weight of moisture that was in the sample is obtained.

The density of each specimen was calculated from the testing whereas the moisture content was calculated using the initial weight before the test, and the dry weight after the specimen is dried in an oven. The samples obtained shall be weighed immediately after cutting. If the test pieces cannot be weighed immediately, placed them inside a plastic bag to protect them from moisture changes. The sides of the cross section and the length along the axes of symmetry of the sample are measured to the nearest $0.1 \mathrm{~mm}$. All samples were dried in an oven at the temperature of $103 \pm 3{ }^{\circ} \mathrm{C}$ for 24 hours or until constant weight are obtained. The samples are weighed again in order to obtain the oven-dry weight. 
The dimensions of the samples are measured again to obtain the oven-dry volume. Thus, density is calculated using the formula given:

Basic Density $\left(\mathrm{g}_{\mathrm{cm}} \mathrm{cm}^{3}\right)=\frac{\text { oven dried weight }}{\text { green volume }}$.

There are four types of strength test were conducted in this study that are the static bending, and compression test. The tests were carried out by using the Universal Testing Machine (UTM) to determine the strength value of the specimens. The static bending test carried out by using the three-point bending method and testing layout as shown in Fig. 2.

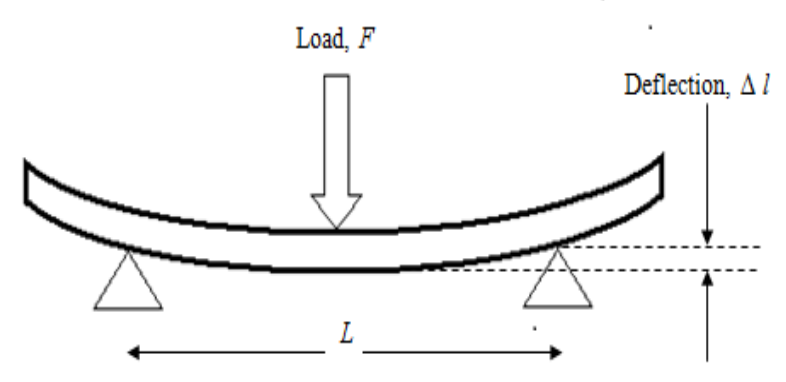

Fig. 2. Static bending testing layout

The purpose of this test is to measure the failure of the sample. The specimen is prepared with dimension $20 \mathrm{~mm} \times 20 \mathrm{~mm} \times 300 \mathrm{~mm}$. The distance between the points of support of the tested specimen is set to be $280 \mathrm{~mm}$, and the contour of the loading head which is in contact with the beam will have a radius of $30 \mathrm{~mm}$. In order to prevent the longitudinal stress and the restrained produce by friction, the specimen is supported at the end to ensure the free flow of the sample when applied with bending stress. A constant loading speed of $0.6 \mathrm{~mm}$ per minute is being applied throughout the test. The deflection of the beam at mid length shall be measured with reference to the outer point of loading. The value is obtained by the calculation of modulus of rupture (MOR) and modulus of elasticity (MOE).

$\operatorname{MOR}\left(\mathrm{N} / \mathrm{mm}^{2}\right)=\frac{3 F L}{2 W T^{2}}$,

where $F$-maximum load, $\mathrm{N} ; L$-span, mm; $W$-width, mm; $T$-depth, mm.

$\operatorname{MOE}\left(\mathrm{N} / \mathrm{mm}^{2}\right)=\left(\frac{L^{3}}{4 W T^{3}}\right)\left(\frac{\Delta F}{\Delta L}\right)$,

where $L$-span, $\mathrm{mm} ; W$-width, $\mathrm{mm} ; T$-depth, $\mathrm{mm}$; $\Delta F / \Delta L$-slope of graph, $\mathrm{N} / \mathrm{mm}$.

Compression test is beneficial for testing the strength and serviceability of timber used as a column, post or truss member. This test will give the maximum load and maximum stress exerted by the specimen. In order to determine the compression test, a sample is prepared with dimension $20 \mathrm{~mm}$ × $20 \mathrm{~mm}$ x $60 \mathrm{~mm}$ and placed vertically on a metal plate while another plate placed above it. The force applied parallel to grain was exerted on the sample by pushing down the top plate and testing layout as shown in Fig. 3. The top compression platen shall be kept parallel to the bottom platen throughout the test. A constant loading speed of $0.6 \mathrm{~mm}$ per min is applied during the test. The maximum load is determined, and the compression stresses are calculated.

Compressive stress at maximum $\left(\mathrm{N} / \mathrm{mm}^{2}\right)=\frac{F}{A}$,

where $F$-maximum load, $\mathrm{N} ; A$-cross sectional area, $\mathrm{mm}^{2}$.

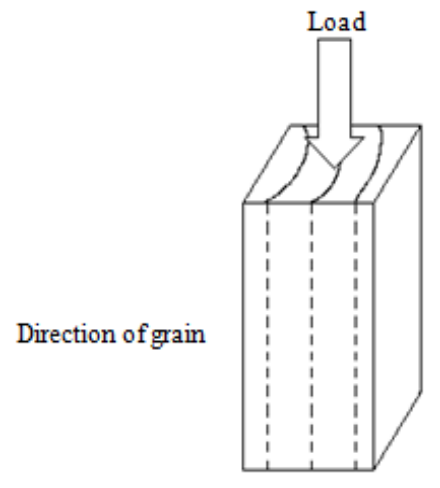

Fig. 3. Compression parallel to grain testing layout

\section{RESULTS AND DISCUSSION}

\subsection{Testing result}

From the study, Table 1 shows that the mean value of strength and physical properties took during the experiment is grouped accordingly to the condition of the specimen that is in green and dry condition. Though the strength value for the dry specimen is slightly greater than that in the green condition, however, modulus of elasticity instead was recorded of less increment of strength only about 24 to 33 percent ranging 9700 to $11000 \mathrm{MPa}$ compare to the modulus of rupture.

Meanwhile, the results obtained from compression parallel to grain and modulus of rupture are proportionately parallel each other with increment 40 to 60 percent ranging 37 to $43 \mathrm{MPa}$ and 75 to $92 \mathrm{MPa}$ in dry condition respectively. The value of moisture content for Endospermum diadenum species at the green condition at a range of 56 to 71 percent and meanwhile at the dry condition drop more than 80 percent. However, a factor dependency of changing in condition from green to the dry condition is not significant influence the basic density of timber that is about 19 to 32 percentage. The water plays important role influence the strength of wood with lower moisture content will have higher strength compared to the wood with higher moisture content. In fact, the more the timber dried, the greater would be the strength of timber [12]. However, another factor such as heterogeneous, where this characteristic is prompt to fluctuate in its strength properties even though the same species [13]. Winandy in his study, has concluded that factors that affect the strength properties can be simplified into two factors, there are anatomical and environmental factors [14].

\subsection{Distribution of bending strength at different distance from the vortex}

In both green and dry condition as shown in Fig. 4 and Fig. 5, the modulus of rupture is directly proportional to the distance from the vortex or pith with 5 percent significance level. 
Table 1. Summary of the mean physical and strength properties of Endospermum diadenum

\begin{tabular}{|c|c|c|c|c|c|c|c|c|}
\hline \multirow{2}{*}{\multicolumn{2}{|c|}{$\begin{array}{l}\text { Condition } \\
\text { Tree No. }\end{array}$}} & \multirow{2}{*}{ Unit } & \multicolumn{3}{|c|}{ Green $\mathrm{MC}>19 \%$} & \multicolumn{3}{|c|}{ Dry $\mathrm{MC}<19 \%$} \\
\hline & & & TR008 & TR010 & TR013 & TR008 & TR010 & TR013 \\
\hline \multirow{12}{*}{ 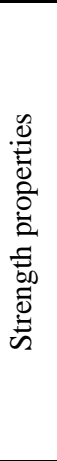 } & \multirow{4}{*}{ Modulus of rupture } & $\mathrm{MPa}$ & 58.80 & 51.84 & 52.18 & 92.92 & 85.71 & 75.08 \\
\hline & & SD & 7.00 & 7.81 & 6.99 & 13.26 & 8.58 & 10.04 \\
\hline & & $\mathrm{CV} \%$ & 11.90 & 15.06 & 13.40 & 14.27 & 10.01 & 13.37 \\
\hline & & Nos & 36.00 & 36.00 & 36.00 & 36.00 & 36.00 & 36.00 \\
\hline & \multirow{4}{*}{$\begin{array}{l}\text { Modulus of } \\
\text { elasticity }\end{array}$} & $\mathrm{MPa}$ & 8486.86 & 7838.67 & 8053.14 & 11351.03 & 9746.83 & 9971.98 \\
\hline & & SD & 1032.15 & 1572.75 & 1189.90 & 1731.08 & 1116.93 & 1058.68 \\
\hline & & $\mathrm{CV} \%$ & 12.16 & 20.06 & 14.78 & 15.25 & 11.46 & 10.62 \\
\hline & & Nos & 36.00 & 36.00 & 36.00 & 36.00 & 36.00 & 36.00 \\
\hline & \multirow{4}{*}{$\begin{array}{l}\text { Compression } \\
\text { parallel to grain }\end{array}$} & $\mathrm{MPa}$ & 25.54 & 29.46 & 24.97 & 42.05 & 43.41 & 37.99 \\
\hline & & SD & 3.32 & 5.29 & 2.42 & 9.42 & 5.25 & 7.00 \\
\hline & & $\mathrm{CV} \%$ & 13.00 & 17.95 & 9.68 & 22.40 & 12.10 & 18.43 \\
\hline & & Nos & 36.00 & 36.00 & 36.00 & 36.00 & 36.00 & 36.00 \\
\hline \multirow{8}{*}{ 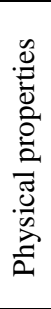 } & \multirow{4}{*}{ Moisture content } & $\%$ & 56.56 & 66.03 & 71.40 & 9.17 & 7.50 & 7.37 \\
\hline & & SD & 13.41 & 17.41 & 14.83 & 3.38 & 0.34 & 0.29 \\
\hline & & $\mathrm{CV} \%$ & 23.71 & 26.38 & 20.77 & 36.87 & 4.50 & 3.96 \\
\hline & & Nos & 36.00 & 36.00 & 36.00 & 36.00 & 36.00 & 36.00 \\
\hline & \multirow{4}{*}{ Basic density } & $\mathrm{g} / \mathrm{cm}^{3}$ & 0.56 & 0.63 & 0.62 & 0.45 & 0.45 & 0.42 \\
\hline & & SD & 0.04 & 0.06 & 0.08 & 0.03 & 0.03 & 0.03 \\
\hline & & $\mathrm{CV} \%$ & 7.40 & 9.59 & 12.51 & 7.66 & 7.11 & 7.94 \\
\hline & & Nos & 36.00 & 36.00 & 36.00 & 36.00 & 36.00 & 36.00 \\
\hline
\end{tabular}

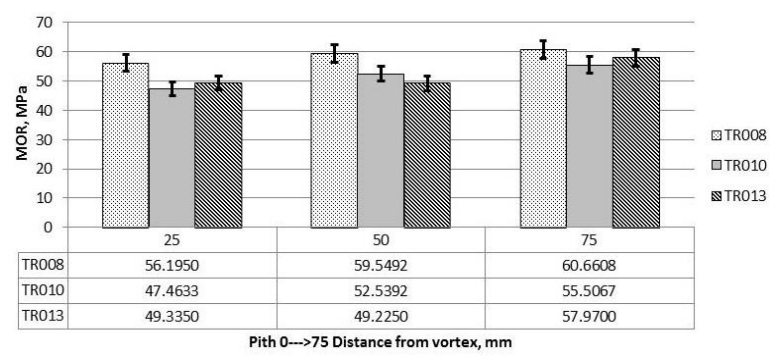

Fig. 4. Modulus of rupture vs distance from pith (green)

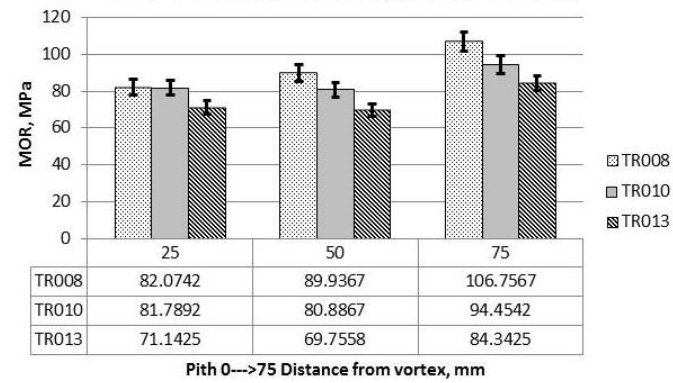

Fig. 5. Modulus of rupture vs distance from pith (dry)

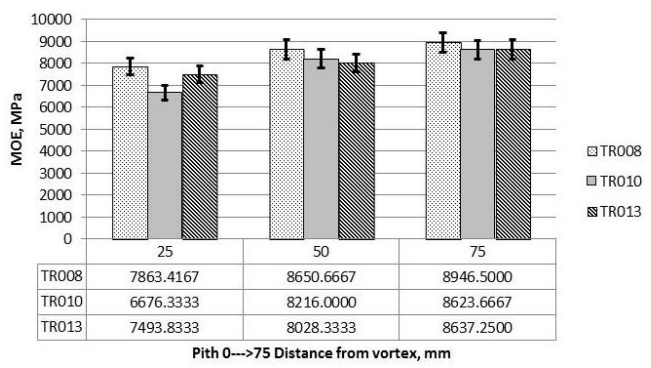

Fig. 6. Modulus of elasticity vs distance from pith (green)

The average mean modulus of rupture for TR008, TR010, and TR013 at green condition increased strength 5 percent ranging 47 to $59 \mathrm{MPa}$ from 25 towards $50 \mathrm{~mm}$ distance and continue to increase 8 percent ranging 49 to $60 \mathrm{MPa}$ from 50 towards $75 \mathrm{~mm}$. Meanwhile at dry condition the average mean modulus of rupture at 25 towards $50 \mathrm{~mm}$ distance with a minimal increment of strength only 2 percent ranging 69 to $89 \mathrm{MPa}$ and large increment of strength experience from 50 towards $75 \mathrm{~mm}$ distance with 19 percent increment ranging 69 to $106 \mathrm{MPa}$. The results obtained from modulus of elasticity at green condition as shown in Fig. 6 observed with 5 percent significance level give average mean with 13 percent strength increment ranging 6600 to $8600 \mathrm{MPa}$ at a distance 25 towards $50 \mathrm{~mm}$ and minimal strength increment with 5 percent ranging 8200 to $8900 \mathrm{MPa}$ from 50 towards $75 \mathrm{~mm}$ distance.

Average mean modulus of elasticity at dry condition as shown in Fig. 7 observed with 5 percent significance level vice versa where only 5 percent strength increment ranging $8900 \mathrm{MPa}$ to $11200 \mathrm{MPa}$ from 25 towards $50 \mathrm{~mm}$ distance and tremendously increased at 18 percent ranging 9300 to $13000 \mathrm{MPa}$ from 50 towards $75 \mathrm{~mm}$ distance.

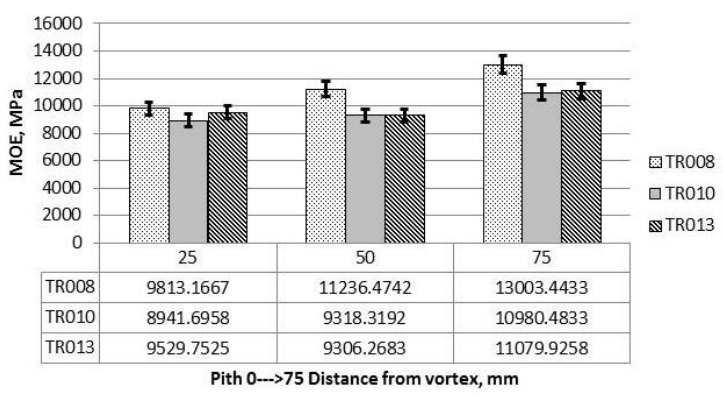

Fig. 7. Modulus of elasticity vs distance from pith (dry)

This result has been proved by the study conducted by Andrew and Alik where the modulus of elasticity of the logs at the centre was about $16.2 \%$ lower as compared to good correlation between the centre of the log [15]. Apart from that, the relationship between modulus of elasticity and the distance from pith shown in Fig. 6 and Fig. 7 also have the similarity in distribution. These values also indicate that the distance from pith towards the sapwood in green condition 
is less prone to elasticity compared to in dry condition. Thought the increment of strength in green condition at sapwood is greater than in dry condition, however, modulus of elasticity at dry condition much better than in green condition as indicated in Table 1 . The primary function of sapwood which is to support and to conduct water to the tree, make it active and stronger compared to heartwood which is primarily inactive. Meaning that, the further the specimen from the pith, the greater the strength value will be [16].

According to the research carried by Alik regarding on the strength properties of Acacia mangium grown in Sarawak, the modulus of rupture and modulus of elasticity of Acacia mangium are also directly proportional to the distance from the pith [17]. This shows the specimen near to the pith have lower strength compare to the specimen away from the pith. As the distance of the specimen from the pith is increased, the strength value becomes greater. In specifications for structural timber seasoned beam at radial, its resistance may influence due to horizontal shear when the pith located in the middle half of the section [18].

\subsection{Distribution of compressive strength different distance from the vortex}

The average mean for compression parallel to grain for TR008, TR010 and TR013 at both green and dry condition were observed as shown in Fig. 8 and Fig. 9 with 5 percent significance level. Fig. 8 shows that 16 percent strength increment ranging 22 to $30 \mathrm{MPa}$ from 25 towards $50 \mathrm{~mm}$ distance and the strength increment almost constant with 15 percent at a distance 50 towards $75 \mathrm{~mm}$ ranging 24 to $34 \mathrm{MPa}$ in green condition. A similar pattern in dry condition where the average mean with 19 percent increased ranging 30 to $41 \mathrm{MPa}$ at distance 25 towards $50 \mathrm{~mm}$ and 20 percent strength increased ranging 38 to $50 \mathrm{MPa}$ at distance 50 towards $75 \mathrm{~mm}$.

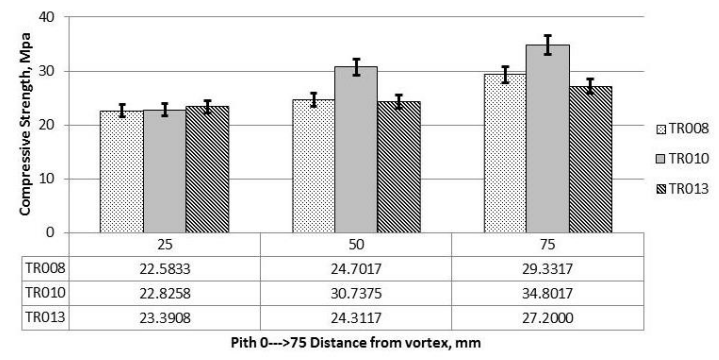

Fig. 8. Compressive strength vs distance from pith (green)

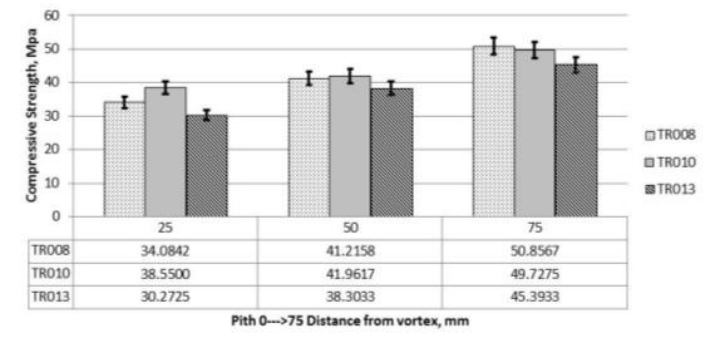

Fig. 9. Compressive strength vs distance from pith (dry)

Referring to the Fig. 8 and Fig. 9, it is clearly seen that, the compression strength is directly proportional to the distance from the pith. In terms of the distance from the pith, the value increase at the distance of $25 \mathrm{~mm}$ away from the pith. The constant increment is observed at the distance of $50 \mathrm{~mm}$ towards $75 \mathrm{~mm}$ from the pith. This result also has been proven by a study conducted by Alik where compression strength increases from pith towards the sapwood [17]. If the functions shown are compared to the bending strength functions, an identical function trend is observed. Meaning that, the strength value of Endospermum diadenum increased from it pith toward the sapwood.

\subsection{Distribution of basic density at different distance from the vortex}

Analysing the Fig. 10 and Fig. 11, the basic density increase with the increases in the distance away from the pith. As for green condition, the average mean at distance 25 towards $50 \mathrm{~mm}$ increased 15 percent ranging 0.5 to $0.6 \mathrm{~g} / \mathrm{cm}^{3}$. However, at distance 50 towards $75 \mathrm{~mm}$ with only 7 percent increment ranging 0.5 to $0.7 \mathrm{~g} / \mathrm{cm}^{3}$. Meanwhile at dry condition, the average mean at distance 25 towards $50 \mathrm{~mm}$ recorded with very small increment only 0.4 percent ranging 0.42 to $0.44 \mathrm{~g} / \mathrm{cm}^{3}$. At distance 50 towards $75 \mathrm{~mm}$ density increased up to 10 percent ranging 0.4 to $0.48 \mathrm{~g} / \mathrm{cm}^{3}$. The proportional relationship between basic density and the distance from the pith is very significant, where density increase away from the vortex or pith.

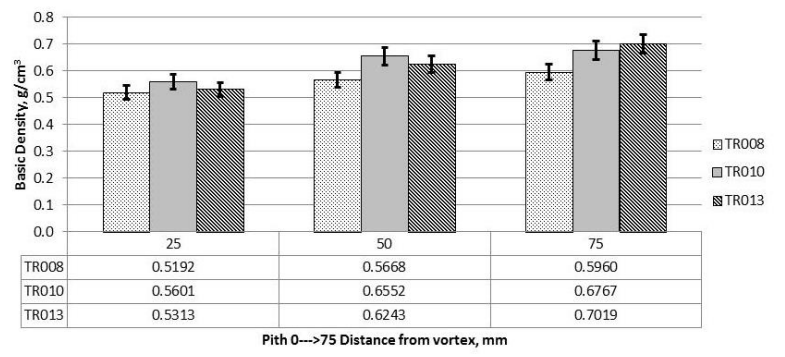

Fig. 10. Basic density vs distance from pith (green)

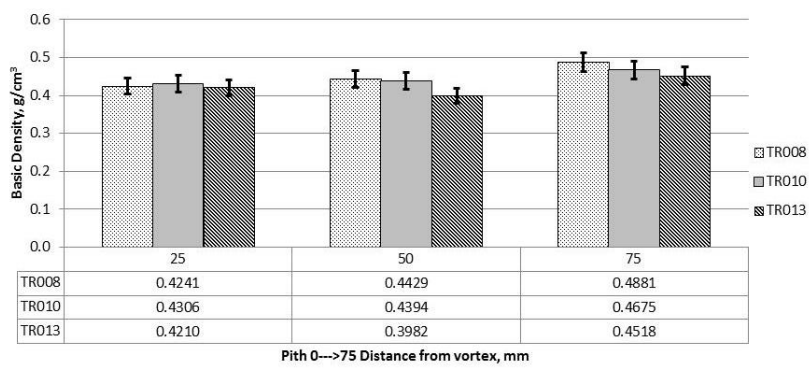

Fig. 11. Basic density vs distance from pith (dry)

The research conducted by by Ditchburne, Kloot and Rumball have showed that the relationships of basic density increase slightly from the pith toward the sapwood [19]. Since the sapwood having higher strength compare to heartwood, this explained that tree with a smaller diameter will have higher strength value compared to a big diameter tree. This is because, the big diameter tree having the bigger heartwood thus resulting in the lower strength value [20].

High growth rate of the tree that is resulting to the vigorous cell division might contribute to the distribution of the density within the tree. The increase in density at outer part of the wood is mainly due to high growth rate which results in vigorous cell division [21] and physiologically active [22]. From this study it is observed that the strength 
properties is directly proportional to it density. McKenzie also observed similar trend where strength properties increase with increasing density [23].

\section{CONCLUSION}

Based on the results obtained in this experimental study regarding the strength properties of Endospermum diadenum at a different distance from the vortex, the following conclusions are made.

1. There are weak correlations between modulus of elasticity in green condition with distance from pith towards the sapwood.

2. The strength increment of modulus of elasticity in green condition at sapwood is greater than in dry condition.

3. Consistence increment of compression strength observed at the distance of $50 \mathrm{~mm}$ towards $75 \mathrm{~mm}$ from the pith.

4. There was a strong relationship between basic density with the distance from the pith.

5. It is recommended that proper selection of cutting method and position contribute significant influence to acquire the type of quality required. Therefore, to acquire good strength quality of wood, cutting position must be at $50 \mathrm{~mm}$ above from the vortex of $200 \mathrm{~mm}$ diameter. For diameter tree bark greater $200 \mathrm{~mm}$, the cutting length from the vortex should be calculated by using equation as below:

$L_{c}(\mathrm{~mm})=\frac{50 \times D_{b}}{200}$,

where $L_{c}$-cutting length from the vortex, mm; $D_{b}$-diameter at breast height over bark of tree, $\mathrm{mm}$.

\section{Acknowledgments}

The authors would like to gratefully acknowledge everyone involves in this project, especially to Ministry of Education Malaysia (MOE) for the research funding (FRGS/TK02(01)/1211/2014(12) and also to Sarawak Forestry Corporation and Universiti Malaysia Sarawak, thank you for the guidance and support.

\section{REFERENCES}

1. Selfbuild Central. Timber Structure. Retrieved December 11, 2012, from Self-Build Central: http://www.selfbuildcentral.co.uk/construction1/roofs/timber-roof-structures/

2. Ismaili, G., Abu Bakar, B.H., Abdul Rahim, K.K. The Behavior of Strength Properties from Three Different Tree Bole of Aras in Sarawak UNIMAS e-Journal of Engineering 2 (2) 2011: pp. $48-52$.

3. Ismaili, G., Abu Bakar, B.H., Duju, A., Abdul Rahim, K.K., and Openg, I. Domination of Grain Bearing on The Strength Properties of Engkabang Jantong as Fast Growing Timber in Sarawak Iranica Journal of Energy \& Environment 4 (3) 2013: pp. 311-315.

4. Ismaili, G. Engineering Properties of Fast Growing Indigenous Timber in Sarawak Compare to Acacia Mangium:
Aras International Journal of Innovative Science and Modern Engineering 3 (2) 2015: pp. 8-12.

5. American Wood Council. Properties of Structural Lumber. In Wood Structural Design Data (p 1). American Wood Council, Washington D.C, 1992.

6. Ismaili, G., Abdul Rahim, K.K., Duju, A., Openg, I., Ismaili, Z. Strength Classification of Aras as fast growing indigenous species timber in Sarawak Applied Mechanics and Materials 695 2015: pp. 617-621.

7. Ismaili, G., Abu Bakar, B.H., Abdul Rahim, K.K. Basic and grade stress for some timber in Sarawak UNIMAS eJournal of Engineering 2(2) 2011: pp. 35-38.

8. American Wood Council. Wood Structural Design Data. American Wood Council, Washington D.C, 2004.

9. Ismaili, G., Abdul Bakar, B.H., Abdul Rahim, K.K. Evaluation of Acacia Mangium in Structural Size at Green Condition UNIMAS e-Journal of Engineering 2 (2) 2011: pp. $17-22$.

10. Cossalter, C., Smith, C.P. Fast-Wood Forestry. Centre of International Forestry Research, Jakarta, 2003.

11. British Standards Institution. Methods of testing small clear specimen of timber, BS 373:1957. British Standards Institution, BSI, London, 1957.

12. Breyer, D.E., Fridley, K.J., Cobeen, E.K., Pollock, D.G. Design of Wood Structure. The McGraw Hill Companies, United States of America, 2007.

13. Ismaili, G. Engineering Properties of Selected Sarawak FastGrowing Indigenous Timber Species. PhD. Thesis. Universiti Sains Malaysia, 2012.

14. Winandy, J.E. Wood Properties. ARNTZEN, C. J. ed. Encyclopaedia of Agricultural Science. Academic Press, Orlando, FL, 1994: pp. 549-561.

15. Nyorik, A., Duju, A. Use of Ultrasonic Wave Method for the Prediction of Some Logs and Sawn Timber Attributes', In: TRTTC/STA, Forest Products Seminar '02, TRTTC/STA 2002: pp. $130-137$.

16. Faherty, K.F., Williamson, T.G. Wood Engineering and Construction Handbook. McGraw Hill Inc., United State of America, 1989.

17. Duju, A. Strength Properties of Acacia Mangium Grown in Sarawak. In: TRTTC/STA, Forest Products Seminar, TRTTC/STA 1999: pp. 158-164.

18. Record, S.J. The Mechanical Properties of Wood. J. Wiley \& Sons, Inc., New Haven, 1924.

19. Ditchburne, N., Kloot, N.H., Rumball, B. The Mechanical Properties of Australian-grown Pinus radiata D. Don, Division of Building Research Technical Paper (Second Series) No.9. Commonwealth Scientific and Industrial Research Organization, Australia 1975: pp. $10-15$.

20. Taylor, A., Franklin, J. Are Fast Grown Trees of Low Quality, University of Tennessee, United State, 2012.

21. Panshin, A.J., Zeeuw, C.D. Textbook of Wood Technology. Mcgraw-Hill, New York, 1980.

22. Pearson, R.G., Kloot, N.H., Boyd, J.D. Timber Engineering Design Handbook. The jacaranda Press, CSIRO, 1962.

23. McKenzie, W.M.C. Design of structural timber. McGrawHill, London, 2000: pp. 5-7. 